\title{
Systematic Review of Clinical and Radiographic Signs of Pediatric Pleomorphic Adenoma of Minor Salivary Glands
}

\author{
Noura A Alsufyani ${ }^{1} \odot$, Adhwa A Altowaijri ${ }^{2}$, Bashayer M Alshehri ${ }^{3}$, Maha S Alsadhan ${ }^{4}$
}

\begin{abstract}
Aim and objective: To examine the clinical signs, radiographical features, and demographics of pediatric pleomorphic adenoma (PA) in the minor salivary glands.

Materials and methods: Several databases were searched for relevant studies. The included studies were assessed for methodological quality. Demographic, clinical, and radiographic data were collected.

Results: Sixteen of 3,121 articles met the inclusion criteria (17 lesions). The mean age was $9.7 \pm 3.9$ years and majority were females $n=10(59 \%)$. It is commonly presented as asymptomatic swelling $n=16(94.1 \%)$, in the hard palate $13(76.5 \%)$. Radiographically, most were well-defined $n=15(93.7 \%)$ and $8(47 \%)$ caused erosion or displacement of surrounding tissues.

Conclusion: The small size and asymptomatic nature of pediatric PA can render these lesions undiagnosed. On rare occurrences, PA can show calcifications, MRI, or CT enhancement. MRI is the best imaging modality to depict soft tissue content but not subtle erosion of adjacent bony structures.

Clinical significance: The dentist can be the first to detect PA in the mouth of a child. Augmenting clinical examination with radiographic examination is paramount to ensure adequate diagnosis of PA, examine effects on surrounding bone, and maintain close follow-up as watchful waiting is not safe in this population.
\end{abstract}

Keywords: CT, Pediatric, Pleomorphic adenoma, Salivary gland, Systematic review.

The Journal of Contemporary Dental Practice (2021): 10.5005/jp-journals-10024-3168

\section{INTRODUCTION}

Pleomorphic adenoma (PA) is the most common salivary gland neoplasm (45-80\%), mainly found in the parotid gland. ${ }^{1,2}$ It presents clinically as a painless, firm, slowly growing mass and with $1.5 \%$ chance for malignant transformation in less than 5 years. ${ }^{3}$ Histologically, it is composed of glandular epithelium and myoepithelial cells with a mesenchymal-like background, hence the synonym "benign mixed tumour."1 In adults, PA most commonly occurs in females, between the ages of 30 and 60 year. 'It presents mostly in major salivary glands (53-70\% in parotid gland), 44-68\% in submandibular gland, and $33-43 \%$ in minor salivary glands. ${ }^{1}$ Around $3-5 \%$ of all salivary gland neoplasms occur in children and adolescents. ${ }^{4,5}$ Similar to adults, the most common site for PA was in the major salivary glands (78-91.6\%), mostly in the parotid gland (66-90\%), and $8.3-47.4 \%$ in minor salivary glands. ${ }^{3,4,6-8}$

The prevalence of PA in minor salivary glands and malignant transformation is higher in children vs adults (47.4 vs $26.4 \%$ ) and (47.4 vs $29.8 \%$ ), respectively. ${ }^{9}$ Recurrence rates are higher in children, up to $23 \%$ in parotid glands, compared to adults due to conservative treatment and longer life expectancy in the pediatric population. ${ }^{7,8}$ The radiographic appearance of PA is well-documented in the major salivary glands with imaging modalities such as ultrasound (US), CT, and MRI; however, it may differ when it comes to minor salivary glands. ${ }^{6}$ The dentist can be the first to detect PA a child either through clinical examination or on radiographic images. The detection of PA in minor salivary glands is challenging because, unlike major salivary glands, these can be distributed throughout the maxillofacial tissues. The literature on PA in children in the minor salivary glands is limited and radiographic analysis of pediatric PA is limited to case reports..$^{8,10,11}$

\begin{abstract}
${ }^{1-4}$ Department of Oral Medicine and Diagnostic Sciences, College of Dentistry, King Saud University, Riyadh, Saudi Arabia

${ }^{1}$ Division of Oral Medicine, Pathology and Radiology, School of Dentistry, Department of Medicine and Dentistry, University of Alberta, Edmonton, Alberta, Canada

Corresponding Author: Noura A Alsufyani, Department of Oral Medicine and Diagnostic Sciences, College of Dentistry, King Saud University, Riyadh, Saudi Arabia; Division of Oral Medicine, Pathology and Radiology, School of Dentistry, Department of Medicine and Dentistry, University of Alberta, Edmonton, Alberta, Canada, Phone: +966118052311, e-mail: ALSUFYAN@UALBERTA.CA
\end{abstract}

How to cite this article: Alsufyani NA, Altowaijri AA, Alshehri BM, et al. Systematic Review of Clinical and Radiographic Signs of Pediatric Pleomorphic Adenoma of Minor Salivary Glands. J Contemp Dent Pract 2021;22(9):1063-1068.

Source of support: Nil

Conflict of interest: None

Depending on the location and size, PA can pose a surgical challenge and risk of recurrence. With higher recurrence rates and malignant transformation, a wait-and-watch approach is not advisable. $^{7}$

Recognizing PA is challenging in the minor salivary glands and in the pediatric population, and delays in diagnosis are devastating given the recurrence and malignant transformation rates. The literature lacks systematic reviews that provide collective data on the most common anatomical sites and radiographic features of pediatric PA. Disseminating this knowledge can increase awareness of PA, improve the diagnosis and, consequently, treatment in the pediatric population.

() The Author(s). 2021 Open Access This article is distributed under the terms of the Creative Commons Attribution 4.0 International License (https://creativecommons. org/licenses/by-nc/4.0/), which permits unrestricted use, distribution, and non-commercial reproduction in any medium, provided you give appropriate credit to the original author(s) and the source, provide a link to the Creative Commons license, and indicate if changes were made. The Creative Commons Public Domain Dedication waiver (http://creativecommons.org/publicdomain/zero/1.0/) applies to the data made available in this article, unless otherwise stated. 
The aim of this systematic review is to assess the available literature pertaining to the demographics, clinical signs, radiographic features, and recurrence of PA in the minor salivary glands of children and adolescents.

\section{Materials and Methods}

Ethical approval or informed consent is not applicable for this type of research.

This systematic review was conducted according to the Preferred Reporting Items for Systematic Reviews and Meta-Analyses (PRISMA) statement. ${ }^{12}$ The protocol for the systematic review was registered on the international prospective register of systematic reviews (PROSPERO) \#CRD42018091487. PICo (population, interest, and context) was used to formulate the focused question: "What are the clinical, radiographic, and demographic features pleomorphic adenoma in minor salivary glands of children and adolescents?"

Population: children (less than 18 years of age)

Interest: the clinical, radiographic, and demographic information.

Context: minor salivary glands

\section{Database Search}

Four electronic databases (PubMed, MEDLINE, Scopus, and Web of Science) and one search engine (Google Scholar) were used to identify studies published in the English language, with no restrictions on year of publication up to the first week of August 2021.

Keywords were applied for each database search as follows: [("Pleomorphic adenoma" OR "Mixed tumor" OR "Salivary gland tumor") AND ("Children" OR "Child" OR "Adolescent" OR "Adolescence" OR "Pediatric" OR "Paediatric") AND ("Diagnostic imaging" OR "Radiography" OR "Radiographic" OR "Three dimensional imaging")] AND [Minor].

\section{Screening and Quality Assessment}

Inclusion criteria were human-child studies, histologically confirmed PA, and reporting radiographic features. Exclusion criteria were editorials, commentaries, and literature reviews.
Three phases of screening were conducted by three examiners (AT, MS, and BS) independently. Discrepancies were resolved through discussion and consultation with independent examiner (NS).

Phase I: Screening the title and abstract for studies resulting from keyword search.

Phase II: Review of full-text of studies included from phase I.

Phase III: Review of full-text of studies manually searched from the reference list/bibliography of studies from phase II.

Studies that satisfied the inclusion criteria were assessed using a modified version of Murad et al.'s risk of bias assessment tool for case reports and case-series. ${ }^{13}$ The tool focuses on elements of selection method, exposure and outcome ascertainment, and sufficient detail. Studies scoring 4 were deemed "high quality-low risk of bias," scoring 3 were "moderate quality and risk of bias," a score of 2 or less were "poor quality-high risk of bias."

\section{Data Analysis}

Primary data collected were age and gender, clinical (location, size, sign or symptoms and their duration), radiographic imaging modality, and radiographic features. Secondary data collected were management/therapy, recurrence, and duration of follow-up. The data were presented in frequency $n(\%)$ for qualitative data, and mean and standard deviation for quantitative data.

\section{RESULTS}

The electronic database search resulted in 3,094 articles. Of these, 16 studies satisfied the inclusion criteria. The numbers of studies screened at each phase are provided in Flowchart 1. The initial examiners' average agreement (kappa score) on quality assessment was 0.81 (range 0.71-0.86). The agreement reached 1.00 after discussion and consensus.

Of the 16, 10 scored high quality and six scored moderate, Table 1. Moderate scores were due to the lack of 3D images, not reporting the internal structure or suboptimal image quality to extract radiographic information.

Flowchart 1: PRISMA flow diagram of article inclusion

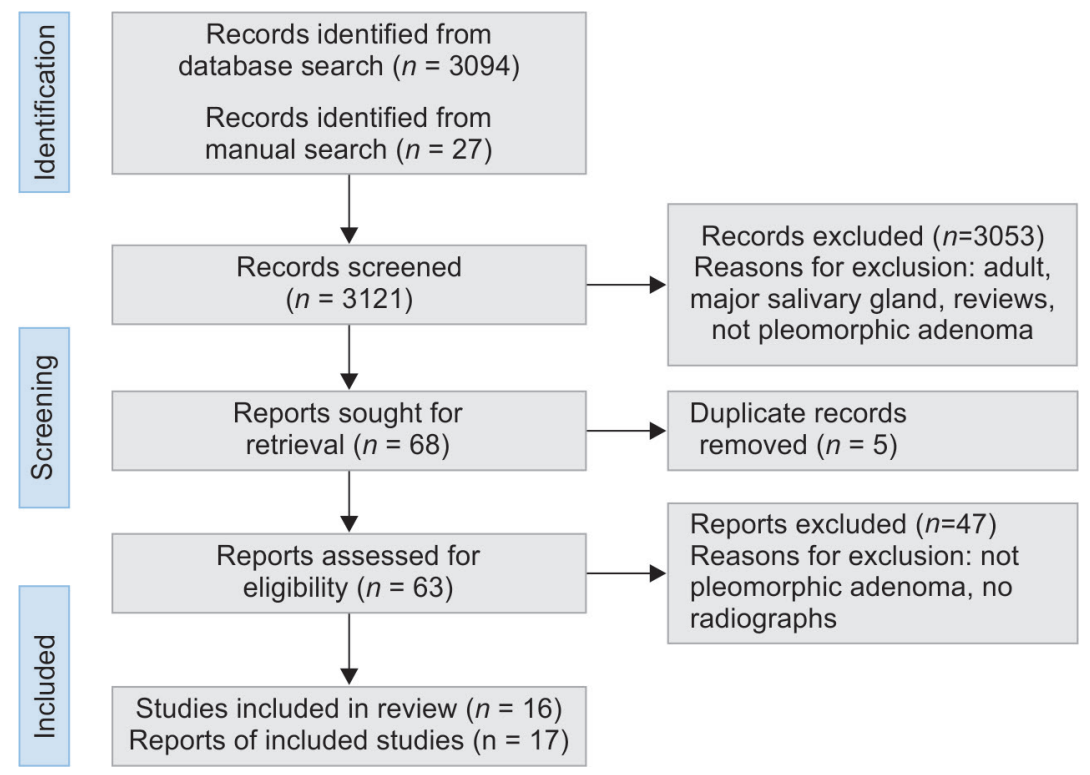


Table 1: Clinical features, management, and recurrence of pleomorphic adenoma collected from the included studies

\begin{tabular}{|c|c|c|c|c|c|c|}
\hline $\begin{array}{l}\text { Study (quality } \\
\text { score, QS) }\end{array}$ & $\begin{array}{c}\text { Age } \\
\text { Gender }\end{array}$ & $\begin{array}{l}\text { Location } \\
\text { Size }(\mathrm{cm})\end{array}$ & Clinical symptoms & $\begin{array}{l}\text { Duration of } \\
\text { symptoms }\end{array}$ & Management & Recurrence \\
\hline $\begin{array}{l}\text { Maclsaac et al. }{ }^{14} \\
\text { (QS high) }\end{array}$ & $\begin{array}{l}7 \\
F\end{array}$ & $\begin{array}{l}\text { Hard palate } \\
\quad 3 \times 5\end{array}$ & Firm painless swelling & 6 months & $\begin{array}{l}\text { Extirpation and } \\
\text { aggressive cauterization }\end{array}$ & None in 5 years \\
\hline $\begin{array}{l}\text { Arcuri et al. }{ }^{23-25} \\
\text { (QS high) }\end{array}$ & $\begin{array}{l}11 \\
M\end{array}$ & $\begin{array}{l}\text { R Hard palate } \\
\quad 2 \times 2\end{array}$ & fluctuant painless swelling & 2 months & Intra-oral resection & - \\
\hline $\begin{array}{l}\text { Bayles et al. }{ }^{15} \text { (QS } \\
\text { high) }\end{array}$ & $\begin{array}{c}1.6 \\
F\end{array}$ & $\begin{array}{l}\text { Mid } 1 / 3 \text { tongue } \\
\quad 3 \times 2 \times 1\end{array}$ & Firm painless swelling & 6 weeks & Wide local excision & $\begin{array}{l}\text { None in } \\
16 \text { months }\end{array}$ \\
\hline $\begin{array}{l}\text { Moubayed et al. }{ }^{16} \\
\text { (QS high) }\end{array}$ & $\begin{array}{c}13 \\
F\end{array}$ & $\begin{array}{l}\text { Hard palate } \\
2 \times 2 \times 2.3\end{array}$ & Firm painless swelling & 2 weeks & $\begin{array}{l}\text { Hemipalatectomy with } \\
\text { excision of deep bony } \\
\text { margin }\end{array}$ & - \\
\hline $\begin{array}{l}\text { Crawford et al. }{ }^{17} \\
\text { (QS moderate) }\end{array}$ & $\begin{array}{l}8 \\
\mathrm{~F}\end{array}$ & $\begin{array}{l}\text { L Hard palate } \\
\quad 2.5\end{array}$ & Firm painless swelling & 3 weeks & Surgical excision & None in 1 year \\
\hline $\begin{array}{l}\text { López-Cedrún } \\
\text { et al. }^{24-26} \text { (QS } \\
\text { moderate) }\end{array}$ & $\begin{array}{l}16 \\
M\end{array}$ & $\begin{array}{l}\text { L Hard palate } \\
\qquad 5\end{array}$ & Firm painless swelling & 2 weeks & Surgical excision & $\begin{array}{l}\text { None in } \\
3.5 \text { months }\end{array}$ \\
\hline $\begin{array}{l}\text { de Courten et al. }{ }^{18} \\
\text { (QS high) }\end{array}$ & $\begin{array}{c}10 \\
F\end{array}$ & $\begin{array}{c}\text { R Hard palate } \\
2.3 \times 2\end{array}$ & $\begin{array}{l}\text { Firm painless } \\
\text { swelling + ulcer }\end{array}$ & 5-6 weeks & Surgical excision & None in 9 years \\
\hline \multirow[t]{2}{*}{$\begin{array}{l}\text { Daniels et al. }{ }^{5} \\
\text { (QS high) }\end{array}$} & $\begin{array}{c}5 \\
M\end{array}$ & $\begin{array}{l}\text { L Hard palate } \\
2 \times 1.5 \\
(2.5 \times 2.5 \text { at } \\
\text { surgery })\end{array}$ & $\begin{array}{l}\text { Fluctuant painless swelling } \\
\text { *with time firm }\end{array}$ & 20 days & $\begin{array}{l}\text { Surgical excision } \\
\text { ( } 2 \text { years after initial visit) }\end{array}$ & None in 3.5 years \\
\hline & $\begin{array}{l}16 \\
M\end{array}$ & $\begin{array}{l}\text { L Hard palate } \\
\qquad 2 \times 2\end{array}$ & Fluctuant tender swelling & 5 months & Surgical excision. & None in 4 years \\
\hline $\begin{array}{l}\text { Hughes et al. }{ }^{19} \text { (QS } \\
\text { moderate) }\end{array}$ & $\begin{array}{l}\text { Teen } \\
\mathrm{F}\end{array}$ & $\begin{array}{l}\text { Soft palate } \\
2 \times 2\end{array}$ & $\begin{array}{l}\text { Firm painless swelling + } \\
\text { change in voice }\end{array}$ & 3 months & $\begin{array}{l}\text { resected via a transoral } \\
\text { approach }\end{array}$ & - \\
\hline $\begin{array}{l}\text { Noghreyan et al. }{ }^{20} \\
\text { (QS moderate) }\end{array}$ & $\begin{array}{l}8 \\
F\end{array}$ & $\begin{array}{l}\text { R Hard palate } \\
2.5 \times 3\end{array}$ & $\begin{array}{l}\text { Fluctuant painless } \\
\text { swelling }\end{array}$ & 2 months & Surgical excision. & $\begin{array}{l}\text { None in } \\
18 \text { months }\end{array}$ \\
\hline $\begin{array}{l}\text { Shaaban et al. }{ }^{25-27} \\
\text { (QS moderate) }\end{array}$ & $\begin{array}{c}9 \\
M\end{array}$ & $\begin{array}{l}\text { L Hard palate } \\
\qquad 2 \times 2\end{array}$ & $\begin{array}{l}\text { Firm painless } \\
\text { swelling + ulcer }\end{array}$ & 4 days & Surgical excision & $\begin{array}{l}\text { Yes in } 2 \text { years } \\
\text { then, } \\
\text { None in } 1 \text { year }\end{array}$ \\
\hline $\begin{array}{l}\text { Swain et al. }{ }^{26-28} \\
\text { (QS high) }\end{array}$ & $\begin{array}{l}13 \\
M\end{array}$ & $\begin{array}{l}\text { L Soft palate } \\
\qquad 3 \times 3\end{array}$ & $\begin{array}{l}\text { Firm painless } \\
\text { swelling + ulcer }\end{array}$ & 1 year & Surgical excision & None in 1 year \\
\hline $\begin{array}{l}\text { Austin and } \\
\text { Crockett }^{21} \text { (QS } \\
\text { moderate) }\end{array}$ & $\begin{array}{c}10 \\
F\end{array}$ & $\begin{array}{l}\text { R Hard palate } \\
\quad 2 \times 3\end{array}$ & Firm painless swelling & 3 weeks & Surgical excision & None in 1 year \\
\hline $\begin{array}{l}\text { Alsufyani }{ }^{22} \text { (QS } \\
\text { high) }\end{array}$ & $\begin{array}{l}9 \\
\mathrm{~F}\end{array}$ & $\begin{array}{l}\text { Hard palate } \\
1 \times 1 \times 0.6\end{array}$ & Firm painless swelling & $\begin{array}{l}\text { Incidental } \\
\text { unaware }\end{array}$ & Surgical excision & $\begin{array}{l}\text { None in } \\
18 \text { months }\end{array}$ \\
\hline $\begin{array}{l}\text { Görürgöz et al. }{ }^{23} \\
\text { (QS high) }\end{array}$ & $\begin{array}{l}10 \\
\mathrm{~F}\end{array}$ & $\begin{array}{c}\text { Cheek } \\
1.5 \times 1 \times 0.4\end{array}$ & $\begin{array}{l}\text { Fluctuant painless } \\
\text { swelling }\end{array}$ & 2 months & Surgical excision & $\begin{array}{l}\text { None in } \\
14 \text { months }\end{array}$ \\
\hline $\begin{array}{l}\text { Lindeboom et al. }{ }^{24} \\
\text { (QS high) }\end{array}$ & $\begin{array}{l}12 \\
M\end{array}$ & $\begin{array}{l}\text { Hard palate } \\
2 \times 2\end{array}$ & Firm painless swelling & 5 years & Surgical excision & $\begin{array}{l}\text { None in } \\
12 \text { months }\end{array}$ \\
\hline
\end{tabular}

The demographic and clinical data collected are detailed in Table 1. The 16 studies consisted of 17 PA lesions, with 10 (59\%) females $^{14-23}$ and 7 (41\%) males ${ }^{5,24-28}$ aged $9.7 \pm 3.9$ years (range 1.6-16). The largest dimension of PA was $2.6 \pm 1 \mathrm{~cm}$ and the most common location was hard palate, 13 (76.5\%), followed by $2(11.7 \%)$ in the soft palate, $1(5.9 \%)$ in the tongue, and 1 (5.9\%) in the cheek. All lesions, except for one, ${ }^{5}$ were nontender and 12 (70.6\%) were firm, 3 (17.6\%) presented with surface ulceration and 1 (5.9\%) with voice change. The duration of the reported clinical symptoms was $6.1 \pm 14.6$ months (range 0.1-60), except for one case ${ }^{22}$ where it was an incidental radiographic finding. All lesions were treated by surgical excision, with hemipalatectomy in one case. ${ }^{16}$ Recurrence was documented in 14 cases; 1 (7.1\%) recurrent case, and no recurrence in the remaining 13 (92.9\%). The follow-up period was $2.4 \pm 2.3$ years (range $0.3-9$ ).

The radiographic data collected are detailed in Table 2. Most lesions were well-defined, 15 (93.7\%), with 1 showing rim enhancement on CT. On CT, 7 were similar in attenuation to muscle and 1 was less in attenuation. On MRI, three PA were reported as hypo-intense to fat in T1, two were reported iso-intense to fluid in $\mathrm{T} 2$ and $\mathrm{T} 1$ fat sat, and one reported high enhancement and calcifications. In terms of effects on surrounding structures (ESS), eight $(47 \%)$ of the PA lesions caused displacement of surrounding bony or soft tissues, and the remaining nine (53\%) had no effects. 
Table 2: Radiographic features of PA collected from the included studies

\begin{tabular}{|c|c|c|c|}
\hline \multirow[b]{2}{*}{ Study } & \multicolumn{3}{|c|}{ Radiographic findings } \\
\hline & $C T$ or $C B C T$ & $M R I$ & Conventional or US \\
\hline Maclsaac et al. ${ }^{14}$ & $\begin{array}{l}\text { Well-defined, rim enhancement } \\
\text { Internal: NR } \\
\text { ESS: cortical expansion }\end{array}$ & Hypointense to fat in $\mathrm{T} 1$ & NR \\
\hline Arcuri et al. ${ }^{25}$ & $\begin{array}{l}\text { Well-defined } \\
\text { Internal: similar to muscle } \\
\text { ESS: cortical displacement }\end{array}$ & - & Panoramic NR \\
\hline Bayles et al. ${ }^{15}$ & $\begin{array}{l}\text { Well-defined } \\
\text { Internal: hypo-attenuation to } \\
\text { muscle } \\
\text { ESS: soft tissue displacement }\end{array}$ & - & - \\
\hline Moubayed et al. ${ }^{16}$ & $\begin{array}{l}\text { Well-defined } \\
\text { Internal: similar to muscle } \\
\text { ESS: bone scalloping }\end{array}$ & Contrast enhanced + calcification & - \\
\hline Crawford and Guernsey ${ }^{17}$ & - & - & $\begin{array}{l}\text { PA, occlusal, extraoral head series: } \\
\text { No bony defect }\end{array}$ \\
\hline López-Cedrún et al. ${ }^{26}$ & $\begin{array}{l}\text { Well-defined } \\
\text { Internal: NR } \\
\text { ESS: none }\end{array}$ & - & - \\
\hline de Courten, et al. ${ }^{18}$ & $\begin{array}{l}\text { Well-defined } \\
\text { Internal: similar to muscle } \\
\text { ESS: cortical displacement }\end{array}$ & - & - \\
\hline \multirow[t]{2}{*}{ Daniels et al. ${ }^{5}$} & $\begin{array}{l}\text { Well-defined } \\
\text { Internal: similar to muscle } \\
\text { ESS: cortical displacement }\end{array}$ & - & $\begin{array}{l}\text { Occlusal: } \\
\text { No bony defect }\end{array}$ \\
\hline & $\begin{array}{l}\text { Well-defined } \\
\text { Internal: similar to muscle } \\
\text { ESS: cortical displacement }\end{array}$ & - & - \\
\hline Hughes et al. ${ }^{19}$ & - & $\begin{array}{l}\text { Well-defined } \\
\text { Isointense to fluid in } \mathrm{T} 2 \text { and } \mathrm{T} 1 \text { fat } \\
\text { saturation } \\
\text { ESS: none }\end{array}$ & - \\
\hline Noghreyan et al. ${ }^{20}$ & $\begin{array}{l}\text { Well-defined } \\
\text { Internal: NR } \\
\text { ESS: none }\end{array}$ & - & - \\
\hline Shaaban et al. ${ }^{27}$ & - & ESS: none & - \\
\hline Swain et al..$^{28}$ & $\begin{array}{l}\text { Well-defined } \\
\text { Internal: similar to muscle } \\
\text { ESS: None }\end{array}$ & - & - \\
\hline Austin and Crockett $^{21}$ & - & $\begin{array}{l}\text { Well-defined } \\
\text { Hypointense to fat T1 } \\
\text { ESS: None }\end{array}$ & - \\
\hline Alsufyani $^{22}$ & $\begin{array}{l}\text { Well-defined } \\
\text { Internal: similar to soft tissue } \\
\text { ESS: cortical displacement }\end{array}$ & - & - \\
\hline Görürgöz et al. ${ }^{23}$ & - & - & $\begin{array}{l}\text { Panoramic: WNL } \\
\text { US: well-defined, low echogenicity, } \\
\text { no bony involvement }\end{array}$ \\
\hline Lindeboom et al. ${ }^{24}$ & & $\begin{array}{l}\text { Well-defined } \\
\text { Hypo-intense to fat T1 } \\
\text { Isointense to fluid in T2 } \\
\text { ESS: None }\end{array}$ & \\
\hline
\end{tabular}

NR, not reported; ESS, effects on surrounding structures

\section{Discussion}

Greater proportion of PA in submandibular salivary glands and minor salivary glands has been reported in children and adolescents, compared to adults. It is uncommon for epithelial tumors to present in children under the age of 10 years. ${ }^{8,9}$ PA shows a higher female predilection in major and minor salivary glands in adults. This review showed 1:1.5 male to female ratio and 10 (58.8\%) 
of the children were $\leq 10$ years old. The included articles represent case reports (rare in age or interesting clinical presentation), thus may explain the younger mean age.

Similar to adults, the most common site of PA in minor salivary glands was in the hard palate ${ }^{5,14,16-18,20-22,24-27}$ (13 out of $17,76.5 \%$ ). Minor salivary glands are also found in the upper or lower lips, parapharyngeal space, and buccal soft tissues. Ectopic minor salivary glands can be found in nasal, ethmoidal, and orbital regions, and PA have been reported in these sites. Other sites recorded by this review were the soft palate, ${ }^{19,28}$ cheek, $^{24}$ and the tongue. ${ }^{15}$

Pediatric PA in the minor salivary glands was $2.7 \pm 1 \mathrm{~cm}$ which is smaller than PA in major salivary glands tend to reach a larger size; 4-6 cm. ${ }^{6-8}$ This can be explained by the fact that major salivary glands are not easily palpated by the tactile tongue or visible during a clinical dental examination.

Minor salivary gland tumors tend to be fixed whereas in the parotid they tend to be larger and mobile. ${ }^{6}$ Five $e^{5,20,24,25}$ PAs of the hard palate reported fluctuant center with one becoming firm with time. It appears that with hard palate lesions $\geq 2 \times 2 \mathrm{~cm}$ in size, these seem to develop surface ulceration, Table 1. The duration of swelling varied significantly (from 4 days to 5 years) and thus not reliable. It is important to consider that young children may not be aware or alert to changes in their oral cavity. Although parents may be involved in their child's dental hygiene routine, inspection of their oral cavity may not be a regular exercise but perhaps it should be.

Common imaging modalities used to asses PA are ultrasound US, CT, and MRI, with US being the least common due to its limited usefulness in preoperative diagnosis and planning. ${ }^{6}$ Of the 17 PAs, 10 were imaged with CT, 1 cone beam CT, 6 with MRI, 5 with conventional radiographs, and 1 with US. Conventional radiographs failed to reveal bony defects associated with the PA. Occlusal radiographs may show bony erosion of the hard palate if the PA is of adequate size or optimum angulation in relation to the X-ray beam to capture the radiopaque cortex of the bony erosion/depression. As such, extraoral head series may prove futile. CT offers short scan time and high spatial resolution but utilizes ionizing radiation whereas MRI offers nonionizing radiation, superior soft tissue imaging, and longer imaging time. Since MRI is the preferred choice for postoperative imaging, preoperative MRI of major salivary glands is more common than minor salivary gland lesion and generally encouraged. ${ }^{6}$ The best preoperative imaging should be based on risk-benefit weighing for each tumor site. ${ }^{6}$

On CT/CBCT, PA lesions were well-defined with one showing rim enhancement and resemble soft tissue density (muscle). PA in the minor salivary glands tends to be smooth, with lobulated lesions more commonly occurring in the parotid gland. ${ }^{6,29,30}$ Detectability of PA was higher on axial contrast-enhanced CT images. ${ }^{29}$ The use of contrast in CT will enhance the PA lesion and may improve the visualization of the pseudo-capsule. ${ }^{29}$ Based on CT appearance, the differential diagnosis may include soft tissue tumors such as fibroma, lipoma, neurofibroma, and neurilemmoma.

On MRI, PA has variable intensities, moderately and heterogeneously enhancing. ${ }^{6,30}$ This review revealed six cases that utilized MRI, but not all studies fully described the signal intensities. PA was hypo-intense to fat in $\mathrm{T} 1^{14,21,24}$ and iso-intense to fluid in T2 and T1-fat saturated images, ${ }^{19}$ and one reported high enhancement and calcifications. ${ }^{16}$ Tumor detectability is best (88\%) on axial T2-weighted MRI compared to T1 and CE-T1 weighted images (86 and $85 \%$, respectively), and capsule detection is best on T2 over CE T1 weighted images (90 vs $57 \%) .{ }^{29}$ PA can manifest focal calcifications due to tissue degeneration and these are usually minute. ${ }^{6,29,31}$

Seven (46.7\%) PAs of the hard palate showed evidence of cortical erosion or displacement, and the one PA of the tongue displaced the immediate surrounding soft tissues. Studies that reported no effects on surrounding structures were based on conventional images $(n=1), \mathrm{MRI}(n=3)$, and CT $(n=3)$. PA may depict more growth toward the oral cavity than the nasal cavity resulting in a larger clinically visible swelling and lack of bony erosion. However, the bony effect may not be detectable by the chosen imaging modality. Bone resorption of the hard palate was seldom detected on MRI and is best detected on axial-CT or confirmed at the time of surgery. ${ }^{29}$

The optimal treatment for PAs is wide surgical excision with negative margins. ${ }^{8}$

The pseudo-capsule with tissue nodules within and surrounding the tumor may rupture during the surgical excision, and recurrence may develop. All lesions included in this review were treated by surgical excision, with hemi-palatectomy in one case. ${ }^{16}$ The authors describe wide surgical resection of the palatal bone without justification for the chosen treatment. ${ }^{16}$ It is assumed that the "rapid progressive nature," i.e., 2 weeks duration, was the reason.

The chances of recurrence in children are higher due to the smaller anatomy and tendency toward conservative surgery. ${ }^{7}$ PA recurrence is higher in parotid glands due to location and difficulty in the operative approach, compared to minor salivary glands. ${ }^{6}$ Moreover, longer life expectancy in the pediatric population contributes to higher recurrence rate and risk of malignant transformation. ${ }^{6,7}$ The rate of carcinoma in recurrent PAs is reported between 1.5 and $23 \%{ }^{6,8}$

Recurrence was documented in 14 cases and only 1 (7.1\%) presented with recurrence after 2 years of follow-up. However, the mean follow-up period was $2.6 \pm 2.4$ years (range $0.3-9$ ) and there are documented recurrences up to 30 years after initial resection. ${ }^{8}$ So, it is possible that with longer follow-ups these rates would change.

The main shortcoming of this systematic review is due to the nature of included studies: limited to English language, case reports, variability in radiographic images selected, and lack of uniformity in radiographic description. Including detailed radiographic features in future studies of pediatric salivary gland pathologies, with large sample sizes, and long follow-up durations would allow for robust systematic reviews.

\section{CONCLUSION}

This review revealed that pediatric PA of the minor salivary glands showed female predilection, mostly as an asymptomatic, firm, nonmobile swelling in the hard palate. MRI is the optimum imaging modality showing low-signal in $\mathrm{T} 1$ and high in $\mathrm{T} 2$, with possible enhancement and internal calcification. Imaging with CT was key to highlight erosive effects on the adjacent bony structures which presented in half of the cases. The follow-up duration was not sufficient to reflect a meaningful recurrence rate.

\section{Clinical Significance}

The dentist can be the first to detect PA in the mouth of a child. Augmenting clinical examination with radiographic examination is paramount to ensure adequate diagnosis of PA, examine effects on surrounding bone, and maintain close follow-up as watchful waiting is not safe in this population. 


\section{OrCID}

Noura A Alsufyani 다. https://orcid.org/0000-0002-7627-5073

\section{References}

1. Eveson JW, Cawson RA. Tumours of the minor (oropharyngeal) salivary glands: a demographic study of 336 cases. J Oral Pathol 1985;14(6):500-509. DOI: 10.1111/j.1600-0714.1985.tb00522.x.

2. Spiro RH. Salivary neoplasms: overview of a 35-year experience with 2,807 patients. Head Neck Surg 1986;8(3):177-184. DOI: 10.1002/ hed.2890080309.

3. Araya J, Martinez R, Niklander S, et al. Incidence and prevalence of salivary gland tumours in Valparaiso, Chile. Med Oral Patol Oral Cir Bucal 2015;20(5):e532-e539. DOI: 10.4317/medoral.20337.

4. Forty MJ, Wake MJ. Pleomorphic salivary adenoma in an adolescent. Br Dent J 2000;188(10):545-546. DOI: 10.1038/sj.bdj.4800534.

5. Daniels JS, Ali I, Al Bakri IM, et al. Pleomorphic adenoma of the palate in children and adolescents: a report of 2 cases and review of the literature. J Oral Maxillofac Surg 2007;65(3):541-549. DOI: 10.1016/j. joms.2006.08.005.

6. Dombrowski ND, Wolter NE, Irace AL, et al. Pleomorphic adenoma of the head and neck in children: presentation and management. Laryngoscope 2019;129(11):2603-2609. DOI: 10.1002/lary.27590.

7. Fang QG, Shi S, Li ZN, et al. Epithelial salivary gland tumors in children: a twenty-five-year experience of 122 patients. Int J Pediatr Otorhinolaryngol 2013;77(8):1252-1254. DOI: 10.1016/j. ijporl.2013.04.034.

8. Fu $\mathrm{H}$, Wang J, Wang $\mathrm{L}$, et al. Pleomorphic adenoma of the salivary glands in children and adolescents. J Pediatr Surg 2012;47(4):715-719. DOI: 10.1016/j.jpedsurg.2011.10.067.

9. Gontarz M, Wyszyńska-Pawelec G, Zapała J. Primary epithelial salivary gland tumours in children and adolescents. Int J Oral Maxillofac Surg 2018;47(1):11-15. DOI: 10.1016/j.ijom.2017.06.004.

10. Mamlouk MD, Rosbe KW, Glastonbury CM. Paediatric parotid neoplasms: a 10 year retrospective imaging and pathology review of these rare tumours. Clin Radiol 2015;70(3):270-277. DOI: 10.1016/j. crad.2014.11.009.

11. da Silva LP, Serpa MS, Viveiros SK, et al. Salivary gland tumors in a Brazilian population: a 20-year retrospective and multicentric study of 2292 cases. J Craniomaxillofac Surg 2018;46(12):2227-2233. DOI: 10.1016/j.jcms.2018.09.028.

12. Liberati A, Altman DG, Tetzlaff J, et al. The PRISMA statement for reporting systematic reviews and meta-analyses of studies that evaluate health care interventions: explanation and elaboration. J Clin Epidemiol 2009;62(10):e1-e34. DOI: 10.1016/j. jclinepi.2009.06.006.

13. Murad MH, Sultan S, Haffar S, et al. Methodological quality and synthesis of case series and case reports. BMJ Evid Based Med 2018;23(2):60-63. DOI: 10.1136/bmjebm-2017-110853.

14. Maclsaac ZM, Naran S, Losee JE. Pleomorphic adenoma: a rare intraoral pediatric tumor. J Craniofac Surg 2013;24(2):669-671. DOI: 10.1097/SCS.0b013e3182802485.
15. Bayles SW, Todd NW, Muller S, et al. Pleomorphic adenoma of the pediatric tongue. Otolaryngol Head Neck Surg 1999;120(6):934-936. DOI: 10.1016/S0194-5998(99)70341-4.

16. Moubayed SP, AISaab F, Daniel SJ. Rapidly progressing palatal pleomorphic adenoma in an adolescent. Int J Pediatr Otorhinolaryngol Extra 2010;5(3):141-143. DOI: 10.1016/j.pedex.2009.08.001.

17. Crawford WH, Guernsey LH. Pleomorphic adenoma of the palate: report of a case. Oral Surg Oral Med Oral Pathol 1967;23(1):116-126. DOI: 10.1016/0030-4220(67)90494-x.

18. de Courten A, Lombardi T, Samson J. Pleomorphic adenoma of the palate in a child: 9-year follow-up. Int J Oral Maxillofac Surg 1996;25(4):293-295. DOI: 10.1016/s0901-5027(06)80060-3..

19. Hughes AL, Yang E, Vargas SO. A pediatric soft palate mass. JAMA Otolaryngol Head Neck Surg 2015;141(4):391-392. DOI: 10.1001/ jamaoto.2014.3722.

20. Noghreyan A, Gatot A, Maor E, et al. Palatal pleomorphic adenoma in a child. J Laryngol Otol 1995;109(4):343-345. DOI: 10.1017/ S0022215100130105.

21. Austin JR, Crockett DM. Pleomorphic adenoma of the palate in a child. Head Neck 1992;14(1):58-61. DOI: 10.1002/hed.2880140113.

22. Alsufyani N. Incidental cone beam CT finding of juvenile pleomorphic adenoma: case report. Case Rep Dent 2020;8862657. DOI: $10.1155 / 2020 / 8862657$.

23. Görürgöz C, Erdem MK, Erdem E. Juvenile pleomorphic adenoma of the cheek: report of a rare case and literature analysis. Pediatr Dent J 2020;30(3):238-244. DOI: 10.1016/j.pdj.2020.05.004.

24. Lindeboom J, Ho JT, Donner N, et al. Pediatric pleomorphic adenoma of the palate. Case Rep Dent 2021;9938672. DOI: 10.1155/2021/9938672.

25. Arcuri F, Grivetto F, Poglio G, et al. Simultaneous palatal pleomorphic adenoma and mandibular keratocystic odontogenic tumor in a pediatric patient. J Craniofac Surg 2011;22(6):2347-2350. DOI: 10.1097/ SCS.0b013e318231e480.

26. López-Cedrún JL, Gonzalez-Landa G, Birichinaga B. Pleomorphic adenoma of the palate in children: report of a case. Int J Oral Maxillofac Surg 1996 06/01;25(3):206-207. DOI: 10.1016/s09015027(96)80031-2.

27. Shaaban $\mathrm{H}$, Bruce J, Davenport PJ. Recurrent pleomorphic adenoma of the palate in a child. Br J Plast Surg 2001;54(3):245-247. DOI: 10.1054/ bjps.2000.3536.

28. Swain SK, Das A, Sahu MC. An unusual presentation of pleomorphic adenoma of the soft palate in a 13-year-old boy - A case report. Pediatr Pol 2016;91(3):265-268. DOI: 10.1016/j.pepo.2016.02.002.

29. Kakimoto N, Gamoh S, Tamaki J, et al. CT and MR images of pleomorphic adenoma in major and minor salivary glands. Eur J Radiol 2009;69(3):464-472. DOI: 10.1016/j.ejrad.2007.11.021.

30. Rodriguez $\mathrm{KH}$, Vargas $\mathrm{S}$, Robson $\mathrm{C}$, et al. Pleomorphic adenoma of the parotid gland in children. Int J Pediatr Otorhinolaryngol 2007;71(11):1717-1723. DOI: 10.1016/j.ijporl.2007.07.019.

31. Liu YJ, Lee YH, Chang HC, et al. Imaging quality of PROPELLER diffusion-weighted MR imaging and its diagnostic performance in distinguishing pleomorphic adenomas from Warthin tumors of the parotid gland. NMR Biomed 2020;33(5):e4282. DOI: 10.1002/nbm.4282. 